"Analysis of start-up challenges of African immigrant-owned businesses in selected craft markets in Cape Town"

Samson Nambei Asoba
Robertson K. Tengeh

Samson Nambei Asoba and Robertson K. Tengeh (2016). Analysis of start-up ARTICLE INFO challenges of African immigrant-owned businesses in selected craft markets in Cape Town. Environmental Economics, 7(2), 97-105.

doi:10.21511/ee.07(2).2016.10

DOI

http://dx.doi.org/10.21511/ee.07(2).2016.10

RELEASED ON

Friday, 03 June 2016

JOURNAL

"Environmental Economics"

FOUNDER

LLC "Consulting Publishing Company "Business Perspectives"

NUMBER OF REFERENCES

0

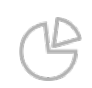

NUMBER OF FIGURES

0

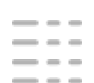

NUMBER OF TABLES

0

(C) The author(s) 2022. This publication is an open access article. 
Samson Nambei Asoba (South Africa), Robertson K. Tengeh (South Africa)

\title{
Analysis of start-up challenges of African immigrant-owned busi- nesses in selected craft markets in Cape Town
}

\begin{abstract}
Even though the arts and craft industry is perceived to be a significant contributor to the socio-economic development of South Africa, the plight of immigrant owed businesses that dominate this sector has been largely neglected in policy and support initiatives over the past decades. This paper aims to contribute to the inclusion debate, by examining the factors that inhibit the start-up of African immigrant-owned craft businesses in selected craft markets in the Cape Town area. A quantitative approach to data collection and analysis was adopted with snowballing as the sampling technique. Questionnaires were administered to 122 African immigrant entrepreneurs. The quantitative data was analysed using the Statistical Package for the Social Sciences (SPSS 23). The findings indicated that limited access to bank loans, limited space, and high rental costs were the major start-up challenges. Other concerns included the relatively very short-stay permits issued by the Department of Home Affairs to immigrant entrepreneurs, the problem of complying with taxation regulations in South Africa, and the difficulty of communicating in Afrikaans and Xhosa were not perceived as start-up challenges. Recommendations were made to African immigrant entrepreneurs and selected municipal managers aimed at dealing with the start-up challenges faced by African immigrant-owned businesses.
\end{abstract}

Keywords: African immigrant entrepreneurs, start-up challenges, craft market, Cape Town.

JEL Classification: M10, M13.

\section{Introduction}

Endowed with a rich heritage and a diversity of wellknown tourist attractions, South Africa continues to attract tourist post 1994. The tourism sector in South Africa is considered to be one of the major contributors to economic development (Rogerson \& Sithole, 2001). As Nyawo and Mubangizi, put it, the growth of the tourism sector has positive spinoffs for related and unrelated businesses such as restaurants and craft markets. Pushed by challenges in the country of origin and lured by opportunities particularly in the craft markets, thousands of African immigrants have migrated to South African in recent years. Thus, Cape Town has become a home to thousands of African immigrant entrepreneurs from African countries such as Zimbabwe, Malawi, Democratic Republic of Congo, Mozambique, Zambia, Tanzania, Kenya, Uganda, Cameroon, Mali and Senegal who depend on the craft industry for livelihood.

Even though the arts and craft industry is perceived to be a significant contributor to the socio-economic development of South Africa, the plight of immigrant owed businesses that dominate this sector has been largely neglected in policy and support initiatives over the past decades (Hunter \& Skinner, 2001; Kaiser \& Associates, 2003; Kaiser \& Associates, 2005; Rogerson, 2010b; Tengeh et al., 2011; Fatoki,

(C) Samson Nambei Asoba, Robertson K. Tengeh, 2016.

Samson Nambei Asoba, Masters Student, Department of Graduate Centre for Management, Faculty of Business and Management Sciences, Cape Peninsula University of Technology, South Africa.

Robertson K. Tengeh, Department of Entrepreneurship and Business Management, Faculty of Business and Management Sciences, Cape Peninsula University of Technology, South Africa.
2014). Notwithstanding the prevalence of these studies, specific attention yet to be given to the factors that affect the start-up of African immigrantowned craft businesses. More so, the factors that inhibit the start-up of these businesses have not been studied in the context of craft businesses in South Africa. Accordingly, the objective of this study was to determine the challenges that African immigrantowned craft businesses faced during start-up phase.

\section{Literature review}

1.1. Immigrant entrepreneurs. The word 'entrepreneur' comes from the French words entre meaning between and prendre meaning to take (Barringer \& Ireland, 2010). Nieman and Nieuwenhuizen (2009) define an entrepreneur as a person who identifies a gap or need in the market, combines resources and grows a venture to meet that need. He or she bears the risk of the venture and he or she is rewarded with the profit if the business succeeds. Nieman and Nieuwenhuizen (2009) describe entrepreneurship as those activities, characteristics, and economic, social and support mechanisms used to facilitate the expression of entrepreneurial activity. Immigrant entrepreneurship describes those entrepreneurial activities undertaken by immigrants in the host country.

1.2. Craft and an overview of craft industry. People become confused about the definition of craft, as a result of a very diverse range of products commonly being referred to as craft. Many South Africans would not even attempt a definition and might answer by saying 'craft is craft'. Hay (2008) states that the consensus is that the items should be handmade. The Cultural Industries Growth Strategy 
(CIGS) (1998) defines craft as the use of one's hands for the production of useful and decorative items on a small scale. There are six categories of craft: traditional art craft; designer goods; craft art; functional wares; souvenirs; and musical instruments. Adu-Gyamfi and Boahinn (2013) describe several types of craft products: carved figurines and sculpture, painted calabashes, leather products, beads and fabrics. Other items include costumes used in initiation rites, basket devices and African clothes such as a bou-bou (a wide-sleeved robe similar to a caftan). Ndlovu (2011) gives some examples of craft objects: beaded eggs, wooden drums carved from tree trunks, wire baobab trees, windmills made of wire and metal, clay pots, woven grass baskets and wooden vessels.

Globally, craft is a big business and China has dominated this sector for the past decade its strength in mass production and cheap labor force (South Africa, DTI, 2005, p. 12). In India, the craft industry is the second largest employer with an estimated 23 million craft people, and this industry earned 1.65 billion US Dollars in 1999/2000 (Dash, 2011, p. 50). In the USA, the craft industry generated $\$ 10.85$ billion in 1995 and in the United Kingdom, it generated GBP 122 million in 1981 (CIGS, 1998).

In the global craft market, Africa is viewed as a single source despite the fact that there are 53 countries in the African continent. The craft industry contributes $15 \%$ to the GDP of Morocco (CIGS, 1998, p. 17). In 2002, Ghana craft exports contributed 11.3 million US Dollars (Kaiser \& Associates, 2005, p. 30).

In South Africa, craft is one of the entry points into the economy (CIGS, 1998, p. 3). The craft industry generates about R3.5 billion in revenue every year and employs about 1.2 million people (Hay, 2008, p. 5). In view of this several craft developments have taken place in South Africa. For instance, in 1997 the government launched the Cultural Industry Growth Strategy with the objective of creating the South African Craft Industry Report. This culminated in study that spanned craft sectors in Western Cape, Eastern Cape, Northern Cape and KwaZulu Natal. The findings of the study noted the preponderance of craft production in Kwazulu Natal, Mpumalanga, Northern Province and Eastern Cape Province, because it perceived traditional lifestyles. This notwithstanding, Gauteng and the Western Cape Province were to have a high craft production because of complex cultural influences.

In the Western Cape, a study conducted by Heathcock (2000) found that craft production occurred mostly in the Cape Metropolitan area, the Winelands and Garden Route, Hermanus area in the
Overberg, southern West Coast region and Knysna and Plettenberg Bay. The craft sector allegedly contributes a turnover of R100 million to R200 million per annum and employs about $15000-30000$ people (Heathcock, 2000).

In addition, Kaiser and Associates (2003, p. 19) observed that there are 45 craft markets, 250 retail outlets and 53 galleries in the Western Cape. The Western Cape has the highest number of craft markets in South Africa. These craft markets are dominated by African immigrant entrepreneurs from the SADC and the rest of Africa (Kaiser \& Associates, 2003, p. 22). The African immigrant entrepreneurs from the SADC contribute about $78 \%$ of wooden craft in the Western Cape Province, while the rest of African countries contributed 22\% (Mikolo, 2007, p. 34).

\subsection{Why African immigrant entrepreneurs} choose Art and craft businesses. 1.3.1. High unemployment and labor market discrimination. Van Tubergen (2005) asserts that in countries with a high unemployment rate (such as South Africa), immigrants are pushed out of the labor market and the alternative is self-employment. This aligns with the block opportunity or push factor theory which propounds that immigrants suffer discrimination in the host labor market (Bogan \& Darity, 2008). In South Africa, Rankin (2006) notes that numerous requirements prevent firms from hiring immigrants with the requisite skills. Hence, Rogerson (2010) believes that craft enterprises were founded for the purposes of assisting the unemployed, through creating jobs and empowering marginalized groups in rural and peri-urban areas in South Africa. It comes as no surprise that the majority of African immigrants trading at Greenmarket Square cite the lack of employment as the main reason for starting a craft business (Chikamhi, 2011).

1.3.2. Abandoned markets. Halkias, Abadir, Akrivos, Harkiolakis, Thurman \& Caracatsanis (2007) point out that immigrants enter abandoned markets. This view is confirmed by Kaiser and Associates (2003), who suggest that craft traders from the SADC and the rest of Africa dominate the Western Cape craft markets in the absence of a strong indigenous curio and craft-producing sector.

1.3.3. Alien status. According to Steiner (1994), "trader status is a precondition for participation in African art trade. African art traders are members of an alien community...". This status dismisses them from many social obligations or constraints, which could hinder successful economic exchange. Their alien status brings together African immigrants and they form communities. These communities exchange information and share a broad spectrum of 
craft knowledge. Their alien status enables them to sell curios and craftware from their country of origin and other African countries.

1.3.4. Experience with prior knowledge. Shinnar and Young (2008) maintain that the prior experience gained by immigrants in certain economic sectors is critical to their starting their own new venture. Kalitanyi and Visser (2010, p. 379) state that in South Africa, African immigrant entrepreneurs are visible mostly in retail and services sectors such as curios and craft, clothes, food, motor cars, restaurants, music and the import business.

1.4. Challenges in starting a craft business. 1.4.1. Registration and taxation. When compared to other emerging and developed economies, the process of registering a business in South African is considered complex and cumbersome (Kristiansen 2008, cited by Chikamhi, 2011) For instance nine procedural requirements (amounting to 38 days) to need to be followed before a business can be registered and this is often very expensive, especially for foreigners. Chikamhi (2011) found that a significant proportion of African immigrants had no knowledge of how to process and register a business. Those African immigrants who are aware of the registration process are not motivated to start businesses, especially in the craft sector, because of the strict municipality regulatory system. Kristiansen (2008, cited by Chikamhi, 2011) agrees that only a handful of immigrants are aware of the regulatory system, and most of them do not understand how to apply it. In addition, it is difficult to comply with taxation regulations in South Africa because the cost is very high.

1.4.2. Limited or no access to bank loans. The National Credit Regulator (NCR) (2012, p. 55) points out that the most important reason people borrow money is to start or buy a business in South Africa. FinMarkTrust (2006, cited by Fatoki \& Garwe, 2010 ) mentions that only $2 \%$ of SMMEs have access to bank loans in South Africa because of their limited credit history and lack of collateral security. Furthermore, commercial banks are reluctant to grant loans to applicants who do not have irregular income streams, credit history, collateral security, fixed physical address and record-keeping skills. According to Tengeh (2011) finance is a major obstacle to the development of businesses in both developed and developing countries, even more so in the case of foreigners who do not have collateral security and the necessary documentation. Fatoki (2014) further asserts that the absence of financial resources is a stumbling block for a significant proportion of immigrant-owned businesses. Khosa and Kalitanyi (2014) found that the DTI agencies do not coach or provide financial assistance to African immigrant-owned businesses, while Rath (2011) points out that because of lack of capital, a significant proportion of immigrant-owned business fail. Rogerson (2010b, p. 22) suggests that the core challenge to SMMEs is how to secure finance for either start-up or cash flow. Cash flow is critical to obtaining material, equipment, skilled labor and premises. It is suggested that new funding methods should be introduced, possibly by government, to make seed capital available to the entrepreneur without the stringent requirements of commercial banks (GEM, 2013).

1.4.3. Cost of obtaining a visa. Peberdy and Crush (1998) observe that the cost of obtaining visas adds significantly to the running costs of African immigrant-owned businesses in craft markets. The cost of permits varies, depending on the period that immigrants wish to stay in South Africa. The issuing of visas by the Department of Home Affairs is very uncertain. Sometimes African immigrants are given 30 days or less to stay in South Africa, which hampers their ability to trade and plan.

1.4.4. Social capital. Aaltonen and Akola (2012) note that social capital is a resource that immigrant entrepreneurs need, especially during the business start-up phase. But a significant proportion of immigrants do not have the social capital enjoyed by local entrepreneurs. Local entrepreneurs have built networks with customers, suppliers and financial institutions over many years, whereas African immigrant entrepreneurs do not have such connections (Aaltonen \& Akola, 2012). On the other hand, Charman, Peterson and Piper (2012) found that groups of African immigrant entrepreneurs in the 'Spaza' or grocery market business collaborate to secure discount from suppliers and in this way benefit from economy of scale. Khosa and Kalitanyi (2014) suggest that African immigrants should create a networking platform where they can share their challenges and seek possible solutions.

1.4.5. High rental. Carman, Peterson and Piper (2012, cited by Khosa \& Kalitanyi, 2014) state that African immigrant entrepreneurs typically rent their business premises from locals. Khosa and Kalitanyi (2014) point out that high rentals are a challenge to immigrants trying to set up a business. They suggest that partnerships should be formed between local and immigrant entrepreneurs.

1.4.6. Limited business space. Mugobo and Ukpere (2012, cited by Khosa \& Kalitanyi, 2014) in a study on rural entrepreneurship report that $46 \%$ of respondents agreed that limited business space is a challenge to launching a business. Fatoki and Garwe (2010) point out that limited business space impacts on the growth potential of new businesses. Landau 
and Jacobsen (2004) believe that this challenge is acute, especially for immigrants who face discrimination on a daily basis. South Africans get first preference over immigrants (Peberdy \& Crush 1998). In their study, Khosa and Kalitanyi (2014) found that $78.5 \%$ of respondents reported business location to be a challenge, especially to African immigrants. Chikamhi (2011) also reported that traders experienced difficulty in finding a good location at the craft markets.

1.4.7. Lack of knowledge of local languages. There are three languages spoken in Cape Town: English, Afrikaans and Xhosa. Khosa (2014) states that a significant proportion of African immigrants are unable to converse in the local languages and this hinders the smooth running of their businesses. A similar study conducted by Habiyakare et al. (2009) in Finland lamented the Finnish language as an obstacle to immigrant entrepreneurs.

1.4.8. Documentation. Hunter and Skinner (2001) suggest that local government should grant immigrants permits and relax some of the restrictions to enable them to do business. According to Kalitanyi and Visser (2010), the majority of African immigrants do not have business licenses. Chikamhi (2011) conducted a study on the Greenmarket Square and Hout Bay craft markets and found the following: all the participants agreed that they had experienced delays in the issuing of permits by the South African Department of Home Affairs; 10 participants failed to get bank loans because they did not have a South African identity document; and 10 participants were unable to open bank accounts and access valuable services.

\section{Methodology}

A mixed method approach was used to collect and analyse the data in this study. According to Johnson, Onwuegbuzie and Turner (2007), this is a procedure that juxtaposes or combines quantitative and qualitative research methods in order to generate a more wide-ranging understanding of the research problem. Questionnaires (Quantitative) were administered to African immigrant entrepreneurs and indepth interviews (Qualitative) were conducted with municipal managers responsible for the four selected craft markets. Quantitative data was analysed separately using Statistical Packages for Social Sciences (SPSS) software, and face-to-face interviews were analyzed for content. The results of both methods were presented in a tabulated format.

2.1. The targeted population. Zikmund, Babin, Carr, and Griffen (2010) state that a population is a group of inhabitants chosen to participate in a study. The participants were identified through the munici- pal managers' database, with their permission. The targeted population for this study comprized African immigrants at the Greenmarket Square, Stellenbosch, Franschhoek and Hout Bay craft markets, and the municipality managers responsible for managing the selected markets. The researcher selected these markets because they are very popular tourist markets.

2.2. Sample frame. According to Khan (2008), a sample frame is a representative of a group used with a view to obtaining information from the whole group. In South Africa a start-up business is one that has existed for less than forty-two months. The sample frame for this study thus consists of African immigrant-owned businesses that are three or more years old, and located in one of the selected markets.

2.3. Sampling methods. Purposive sampling and snowball sampling techniques were utilized in this study because the researcher had the data on numbers of stalls in each craft market but could not identify the African immigrant entrepreneurs by name. Purposive sampling is a method of sampling in which the researcher selects participants based on their knowledge or experience of the topic being researched (Oppong, 2013). The municipal managers were selected because of their knowledge of managing the markets. The snowball technique was also used in the study to select African immigrant entrepreneurs. In snowball sampling, a few potential respondents are identified to begin with and then asked to recommend others they may know who also meet the required criteria for inclusion in the study (Tengeh, 2011). Snowball sampling is particularly useful when it is difficult to approach the participant directly.

2.4. Sample size. The study utilized Raosoft (2009) software to calculate the sample size. Aiming to uphold a 95\% confidence level (i.e. 5\% error margin), the ideal sample size as recommended by the calculator was 122 . The actual sampling frame consisted of 117 stalls at Greenmarket Square craft market, 25 stalls at Stellenbosch craft market, 15 stalls at Franschhoek craft market and 21 stalls at Hout Bay craft market. The total number of stalls was, therefore, 178.

\section{Presentation and discussion of findings}

\subsection{Understanding of the business registration} process. The findings in Table 1 below show that a majority of $66(55.5 \%)$ respondents disagreed with the statement that a lack of knowledge of how to register a business in South Africa affected them when they started their businesses. The balance of 38 (31.9\%) respondents agreed that a lack of knowledge regarding how to register their businesses was 
a hindering factor. It should be recalled that Chikamhi's (2011) study indicated that the majority of African immigrant entrepreneurs had no knowledge of the business registration process.

Table 1. Lack of knowledge of how to register a business

\begin{tabular}{|c|l|c|c|}
\hline \multicolumn{2}{|c|}{} & Frequency & Valid percent \\
\hline \multirow{4}{*}{ Valid } & No importance & 49 & 41.2 \\
\cline { 2 - 4 } & Some importance & 17 & 14.3 \\
\cline { 2 - 4 } & Moderate importance & 15 & 12.6 \\
\cline { 2 - 4 } & Very important & 18 & 15.1 \\
\cline { 2 - 4 } & Extremely important & 20 & 16.8 \\
\cline { 2 - 4 } & Total & 119 & 100.0 \\
\hline Missing & No response & 3 & \\
\hline Total & 122 & \\
\hline
\end{tabular}

3.2. Taxation compliance. Table 2 below shows that $57(46.7 \%)$ respondents felt that it was of no importance to comply with taxation regulations in South Africa. The balance of 38 (33.9\%) respondents agreed with the statement. This result differs from Chikamhi (2011, p. 55), who found that it is very difficult for foreigners to comply with taxation regulations in South Africa.

Table 2. Very difficult to comply with taxation regulations

\begin{tabular}{|l|l|c|c|}
\hline \multicolumn{2}{|c|}{} & Frequency & Valid percent \\
\hline \multirow{4}{*}{ Valid } & No importance & 57 & 50.9 \\
\cline { 2 - 4 } & Some importance & 6 & 5.4 \\
\cline { 2 - 4 } & Moderate importance & 11 & 9.8 \\
\cline { 2 - 4 } & Very important & 22 & 19.6 \\
\cline { 2 - 4 } & Extremely important & 16 & 14.3 \\
\cline { 2 - 4 } & Total & 112 & 100.0 \\
\hline Missing & No response & 10 & \\
\hline Total & 122 & \\
\hline
\end{tabular}

3.3. High taxes. Table below 3 reveals that a majority of $60(49.2 \%)$ respondents disagreed that taxes are extremely high in South Africa, while 42 $(36.2 \%)$ respondents agreed with the statement. This finding differs from Chikamhi (2011), who found that the majority of African immigrant entrepreneurs could not afford to pay tax.

Table 3. Taxes are extremely high

\begin{tabular}{|l|l|c|c|}
\hline \multicolumn{2}{|c|}{} & Frequency & Valid percent \\
\hline \multirow{4}{*}{ Valid } & No importance & 49 & 42.2 \\
\cline { 2 - 4 } & Some importance & 11 & 9.5 \\
\cline { 2 - 4 } & Moderate importance & 14 & 12.1 \\
\cline { 2 - 4 } & Very important & 17 & 14.7 \\
\cline { 2 - 4 } & Extremely important & 25 & 21.6 \\
\cline { 2 - 4 } & Total & 116 & 100.0 \\
\hline Missing & No response & 6 & \\
\hline Total & 122 & \\
\hline
\end{tabular}

3.4. Access to bank loans. The findings in Table 4 below indicate that an overwhelming majority of 89 (74.8\%) respondents agreed that lack of access to bank loans is a major obstacle to starting a craft business. Only 17 (14.3\%) respondents disagreed with this statement. These findings are in line with the findings of Khosa (2014) and Tengeh (2011) that finance is a major obstacle to starting a business both in the developed and less developed world, and more so when it comes to foreigners who do not have collateral security and documentation.

Table 4. Lack of access to bank loans is a major obstacle to starting a business

\begin{tabular}{|l|l|c|c|}
\hline \multicolumn{2}{|c|}{} & Frequency & Valid percent \\
\hline \multirow{4}{*}{ Valid } & No importance & 13 & 10.9 \\
\cline { 2 - 4 } & Some importance & 4 & 3.4 \\
\cline { 2 - 4 } & Moderate importance & 13 & 10.9 \\
\cline { 2 - 4 } & Very important & 25 & 21.0 \\
\cline { 2 - 4 } & Extremely important & 64 & 53.8 \\
\cline { 2 - 4 } & Total & 119 & 100.0 \\
\hline Missing & No response & 3 & \\
\hline Total & \multicolumn{2}{|l}{} \\
\hline
\end{tabular}

3.5. Networking with customers, suppliers and financial institutions. Table 5 below, shows that a significant majority of 50 (43.9\%) respondents agreed that the lack of a network with customers, suppliers and financial institutions was a challenge during the start-up phase of their business, whereas 39 (34.2\%) disagreed with this statement. This finding is corroborated by Aaltonen and Akola (2012, p. 5), who point out that local entrepreneurs have built networks with customers, suppliers and financial institutions over many years, whereas African entrepreneurs do not have such connections.

Table 5. Lack of building a network with customers, suppliers and financial institutions

\begin{tabular}{|c|l|c|c|}
\hline \multicolumn{2}{|c|}{} & Frequency & Valid percent \\
\hline \multirow{4}{*}{ Valid } & No importance & 29 & 25.4 \\
\cline { 2 - 4 } & Some importance & 10 & 8.8 \\
\cline { 2 - 4 } & Moderate importance & 25 & 21.9 \\
\cline { 2 - 4 } & Very important & 26 & 22.8 \\
\cline { 2 - 4 } & Extremely important & 24 & 21.1 \\
\cline { 2 - 4 } & Total & 114 & 100.0 \\
\hline Missing & No response & 8 & \\
\hline Total & & 122 & \\
\hline
\end{tabular}

3.6. Rental costs of craft business space. As indicated in Table 6 below, a majority of 54 (46.6\%) respondents agreed that a high rental cost of craft space is a challenge to starting a craft business. Only 34 (29.3) respondents disagreed and felt that the high rental cost of craft space was not a challenge to starting a craft business. This finding is supported by Khosa (2014), who found that high 
rental costs are a challenge to immigrants trying to set up a business.

Table 6. High rental costs of craft business space

\begin{tabular}{|c|l|c|c|}
\hline \multicolumn{2}{|c|}{} & Frequency & Valid percent \\
\hline \multirow{4}{*}{ Valid } & No importance & 28 & 24.1 \\
\cline { 2 - 4 } & Some importance & 6 & 5.2 \\
\cline { 2 - 4 } & Moderate important & 28 & 24.1 \\
\cline { 2 - 4 } & Very important & 27 & 23.3 \\
\cline { 2 - 4 } & Extremely important & 27 & 23.3 \\
\cline { 2 - 4 } & Total & 116 & 100.0 \\
\hline Missing & No response & 6 & \\
\hline Total & 122 & \\
\hline
\end{tabular}

3.7. Availability of business space. Table 7 below reveals that an overwhelming majority of 71 $(61.2 \%)$ respondents indicated that limited business space was a challenge to starting a business in the selected craft markets, whereas 23 (19.8\%) disagreed and felt that limited business space was not a challenge.

A study conducted by Mugobo and Ukpere (2012, cited by Khosa, 2014) found that only $46 \%$ of respondents agreed that limited space was a challenge to launching a business.

Table 7. Limited business space

\begin{tabular}{|l|l|c|c|}
\hline \multicolumn{2}{|c|}{} & Frequency & Valid percent \\
\hline \multirow{4}{*}{ Valid } & No importance & 15 & 12.9 \\
\cline { 2 - 4 } & Some importance & 8 & 6.9 \\
\cline { 2 - 4 } & Moderate importance & 22 & 19.0 \\
\cline { 2 - 4 } & Very important & 29 & 25.0 \\
\cline { 2 - 4 } & Extremely important & 42 & 36.2 \\
\cline { 2 - 4 } & Total & 116 & 100.0 \\
\hline Missing & No response & 6 & \\
\hline Total & 122 & \\
\hline
\end{tabular}

3.8. Communication in the local languages (Afrikaans and Xhosa). Table 8 below reveals that a majority of $56(46.7 \%)$ respondents agreed that it was difficult to communicate in Afrikaans and Xhosa and this was a challenge to starting a business. However, 49 (40\%) respondents disagreed with this statement. This finding is similar to the findings of Khosa (2014), who found that significant numbers of African immigrants are unable to converse in the local languages and that this hinders the smooth running of their businesses. A similar study conducted by Habiyakare et al. (2009) in Finland mentioned the Finnish language as an obstacle to immigrant entrepreneurs.

Table 8. It was difficult to communicate in Afrikaans and Xhosa

\begin{tabular}{|c|l|c|c|}
\hline \multicolumn{2}{|c|}{} & Frequency & Valid percent \\
\hline \multirow{3}{*}{ Valid } & No importance & 38 & 31.7 \\
\cline { 2 - 4 } & Some importance & 10 & 8.3 \\
\cline { 2 - 4 } & Moderate importance & 16 & 13.3 \\
\cline { 2 - 4 } & Very important & 21 & 17.5 \\
\hline
\end{tabular}

\begin{tabular}{|l|l|c|c|}
\hline \multirow{2}{*}{} & Extremely important & 35 & 29.2 \\
\cline { 2 - 4 } & Total & 120 & 100.0 \\
\hline Missing & No response & 2 & \\
\hline Total & 122 & \\
\hline
\end{tabular}

3.9. Residence permits. Table 9 below indicates that the majority of respondents, $65(50.6 \%)$, disagreed that the Department of Home Affairs had given them less than 30 days to stay in South Africa and that this did not impede them when starting a business. A group of 37 (38.5\%) participants felt that they were affected by this 30-day limit. According to Peberdy and Crush (1998), the issuing of permits by the Department of Home Affairs is very uncertain, in that sometimes African immigrants are given 30 days or less to stay in South Africa, which hampers their ability to trade and plan.

Table 9. Department of Home Affairs gave me less than 30 days to stay

\begin{tabular}{|l|l|c|c|}
\hline \multicolumn{2}{|c|}{} & Frequency & Valid percent \\
\hline \multirow{4}{*}{ Valid } & No importance & 58 & 50.0 \\
\cline { 2 - 4 } & Some importance & 7 & 6.0 \\
\cline { 2 - 4 } & Moderate importance & 14 & 12.1 \\
\cline { 2 - 4 } & Very important & 12 & 10.3 \\
\cline { 2 - 4 } & Extremely important & 25 & 21.6 \\
\cline { 2 - 4 } & Total & 116 & 100.0 \\
\hline Missing & No response & 6 & \\
\hline Total & & 122 & \\
\hline
\end{tabular}

3.10. Duration of the application process to obtain a stall. Table 10 below shows that a significant majority of 52respondents $(45.2 \%)$ agreed that it took a long time to process their application to obtain a stall, while 39 (33.9\%) of participants disagreed with this statement. This finding is corroborated by that of Kristiansen (2008, cited by Chikamhi, 2011, p. 32) who describes the South African business system as very complex. The system has nine procedural requirements to follow before registering a business and it takes a long time, especially for foreigners, who want to start a business.

Table 10. Long time taken to process my application to obtain a stall

\begin{tabular}{|c|l|c|c|}
\hline \multicolumn{2}{|c|}{} & Frequency & Valid percent \\
\hline \multirow{4}{*}{ Valid } & No importance & 26 & 22.6 \\
\cline { 2 - 4 } & Some importance & 13 & 11.3 \\
\cline { 2 - 4 } & Moderate importance & 24 & 20.9 \\
\cline { 2 - 4 } & Very important & 30 & 26.1 \\
\cline { 2 - 4 } & Extremely important & 22 & 19.1 \\
\cline { 2 - 4 } & Total & 115 & 100.0 \\
\hline Missing & No response & 7 & \\
\hline Total & 122 & \\
\hline
\end{tabular}

3.11. The cost of obtaining a visa. Table 11 below indicates that 49 respondents $(41.5 \%)$ disagreed that the cost of obtaining a visa adds significantly to the cost of starting a craft business, while 49 (39.9\%) 
respondents agreed with this statement. This finding does not align with Peberdy and Crush (1998, p. 36), who found that visa costs do add significantly to the running costs of an immigrant business.

Table 11. The cost of obtaining a visa adds significantly to cost of starting a business

\begin{tabular}{|l|l|c|c|}
\hline \multicolumn{2}{|c|}{} & Frequency & Valid percent \\
\hline \multirow{4}{*}{ Valid } & No importance & 41 & 34.7 \\
\cline { 2 - 4 } & Some importance & 8 & 6.8 \\
\cline { 2 - 4 } & Moderate importance & 22 & 18.6 \\
\cline { 2 - 4 } & Very important & 16 & 13.6 \\
\cline { 2 - 4 } & Extremely important & 31 & 26.3 \\
\cline { 2 - 4 } & Total & 118 & 100.0 \\
\hline Missing & No response & 4 & \\
\hline Total & 122 & \\
\hline
\end{tabular}

3.11. Acquisition of abusiness location. Table 12 below shows that an overwhelming majority of 80 (67.2\%) respondents agreed that it is difficult to acquire a business location in the selected craft market, while $18(15.2 \%)$ respondents disagreed. This finding is supported by Khosa (2014), who found that it took the majority of African immigrant entrepreneurs between 1 and 4 months to secure business premises in Cape Town.

Table 12. Difficult to acquire a business location

\begin{tabular}{|l|l|c|c|}
\hline \multicolumn{2}{|c|}{} & Frequency & Valid percent \\
\hline \multirow{4}{*}{ Valid } & No importance & 14 & 11.8 \\
\cline { 2 - 4 } & Some importance & 4 & 3.4 \\
\cline { 2 - 4 } & Moderate importance & 21 & 17.6 \\
\cline { 2 - 4 } & Very important & 33 & 27.7 \\
\cline { 2 - 4 } & Extremely important & 47 & 39.5 \\
\cline { 2 - 4 } & Total & 119 & 100.0 \\
\hline Missing & No response & 3 & \\
\hline Total & 122 & \\
\hline
\end{tabular}

\section{Conclusion}

Generally, research on immigrant-owned businesses has gained momentum over the past decade. This is particularly true for South Africa where reducing employment and poverty have been an ongoing challenge. While it is debatable, there is overwhelming evidence that to suggest that immigrants contribute positively to the economy of the host country through entrepreneurial activities. Even though the arts and craft industry is perceived to be a significant contributor to the socio-economic development of South Africa, the plight of immigrant owed businesses that dominate this sector has been largely neglected in policy and support initiatives over the past decades. The main objective of this study was to criticallyanalyse the start-up challenges faced by African immigrant-owned businesses in selected craft markets. The results indicate that limited access to bank loans, limited trading space, and high rental cost at the selected craft markets are the main factors inhibiting the start-upof craft businesses. Emanating from the findings of this study, a number of recommendations were made.

Overall immigrants, especially from African countries would want to stake a claim to stay in South Africa, and are particularly optimistic that they can earn their stay by contributing favorably towards the socio-economic development of the country. Cognizant of the need to grow the South African economy, it makes sense that policy initiatives be broadened to include all who can contribute positively to the economy regardless of their origin. On this basis, this paper a makes number of recommendations with regards to immigrant craft businesses.

\section{Recommendations}

Firstly, a major limiting factor identified was the lengthy period of time that it takes to obtain a stall at a craft market. The procedure is complex and applications for stalls take a long time to process. The researcher recommends that municipality managers investigate how to speed up the service delivery process. Local government should grant immigrants permits and relax some of the restrictions to allow them to obtain a stall and do business. The municipality should identify suitable land for SMMEs and informal traders. Secondly, delays in processing documentations were identified as a challenge. Municipality managers should work closely with the Department of Home Affairs and encourage a speedy process to ensure that African immigrants receive their documentation timeously.

\section{References}

1. Aaltonen, S. \& Akola, E. (2012). Lack of trust - the main obstacle for immigrant entrepreneurship? Turku School of Economics, University of Turku, Finland. Available at: http://pyk2.aalto.fi/ncsb2012/Aaltonen.pdf [Accessed: 12 December 2014].

2. Adu-Gyamfi, V.E. \& Boahinn, J.O.B. (2013). The craft industry, oral literature and languages in the development of tourism in Ghana: prospects and challenges, Arts and Design Studies, 14.

3. Baringer. B.R. \& Ireland, R.D. (2010). Entrepreneurship: successfully launching new venture, $3^{\text {rd }}$ ed. Upper Saddle River, NJ: Prentice Hall.

4. Bogan, V. \& Darity, W. Jr. (2008). Culture and entrepreneurship? African America and immigrant selfemployment in the United States, Journal of Socio-Economics, 37, pp. 1999-2019. 
5. Charman, A., Petersen, L. \& Piper, L. (2012). From local survivalism to foreign entrepreneurship: the transformation of the spaza sector in Delft, Cape Town, Transformation: Critical Perspectives on Southern Africa, 78(1), pp. 47-73.

6. Chikamhi, T. (2011). Exploring the challenges facing micro enterprise immigrant traders in the Western Cape metropole: Greenmarket Square and Hout Bay Harbour markets, Master's thesis, University of Cape Town, Cape Town.

7. Cultural Strategy Group. (1998). Creative South Africa. A strategy for realizing the potential of the cultural industries, A report to the Department of Arts, Culture, Science and Technology. Available at: http://www.gov.za/sites/www.gov.za/files/mso1ba_0.pdf [Accessed:15 September 2014].

8. Dash, M. (2011). Marketing of Orissa handicraft: a study on challenges and opportunities, International Journal of Multidisciplinary Management Studies, 1(2), pp. 47-63.

9. Fatoki, O. \& Garwe, D. (2010). Obstacles to growth of new SMEs in South Africa: a principal component analysis approach. African Journal of Business Management, 4(5), pp. 729-738. Available at: http://www. academicjournals.org/AJBM.ISSN 1993-8233. [Accessed: 12 November 2014].

10. Fatoki, O. \& Patswawairi, T. (2012). The motivation and obstacles to immigrant entrepreneurship in South Africa. Journal of Social Sciences, 32(2), pp. 133-142.

11. Fatoki, O. (2014). The financing preferences of immigrant small business owners in South Africa, Mediterranean Journal of Social Science, 5(20), pp. 184-189.

12. GEM (Global Entrepreneurship Monitor). (2013). South Africa report. Twenty years of democracy. Cape Town: The UCT Development Unit for New Enterprise.

13. Halkias, D., Abadir, S., Akrivos, D., Harkiolakis, N., Thurman, P. \& Caracatsanis, S. (2007). Characteristics and business profile of immigrant-owned small firms: the case of Albanian immigrant entrepreneurs in Greece. Hellenic America University, Working Paper 155, pp. 1-29, July.

14. Hay, D. (2008). The business of craft and crafting the business: strategies for success in the rural craft sector. Available at: http://www.tcd.ufl.edu/Data/Sites/44/media/documents/tropilunch/2011/BusinesofCraftHandbook-low resolution.PDF [Accessed: 13 December 2014].

15. Heathcock, S. (2000). Wesgro background report on the craft industry in the Western Cape. Available at: http://ccdi.org.za/research-and-publications/research/Craft\%20Industry\%20in\%20the\%20Western\%20Cape.pdf [Accessed: 14 December 2014].

16. Hunter, N. \& Skinner, C. (2001). Foreign traders working in inner city Durban: survey results and policy dilemmas. School of Development Studies (Incorporating CSDS) University of Natal, Durban. Research Report No. 49.

17. Kaiser \& Associates. (2003). Strategic recommendations for the development of the craft industry in the Western Cape: discussion guide. Prepared for the Cape Craft and Design Institute by Kaiser \& Associates. CCDI report No 5/2003, July.

18. Kaiser \& Associates. (2005). Western Cape microeconomic development strategy: craft sector study. Overall executive summary. 27 May 2005.

19. Kalitanyi, V. \& Visser, H. (2010). African immigrants in South Africa: job takers or creators? South African Journal of Economic Management, 13(4), pp. 376-390.

20. Khosa, R.M. (2014). An analysis of challenges in running micro-enterprises: a case of African foreign entrepreneurs in Cape Town, Western Cape. Unpublished Master's thesis. Cape Peninsula University Technology, Cape Town.

21. Landau, L.B. \& Jacobsen, K. (2004). Refugees in the New Johannesburg, Forced Migration Review, 19 , pp. $44-46$.

22. NCR (National Credit Regulator). (2012). Credit and borrowing in South Africa. FinScope Consumer survey South Africa. Available at: http://www.ncr.org.za/press_release/research_reports/NCR_14.03.2013.pdf [Accessed: 12 September 2014].

23. Mikolo, Y.C.(2007). Livelihood and income generation from the wood carving trade in the Cape Town area of the Western Cape Province, South Africa. Unpublished Master's thesis, University of Stellenbosch, Cape Town.

24. Ndlovu, M. (2011). The small is big: craft in the inner city of Johannesburg. Available at: http://lec.sagepub.com/content/26/1/43 [Accessed: 23 January 2015].

25. Nieman, G. \& Nieuwenhuizen C. (2009). Entrepreneurship: a South African perspective. $2^{\text {nd }}$ ed. Pretoria: Van Schaik.

26. Nyawo, J. \& Mubangizi, B.C. (2015). Art and Craft local economic development: tourism possibilities in Mtubatuba Local Municipality, African Journal of hospitality, Tourism and leisure, 4(2), pp. 1-15.

27. Peberdy, S. \& Crush, S. (1998). Trading places: cross-border traders and the South African informal sector. Migration Policy Series No: 6. Cape Town: IDASA.

28. Rankin, N. (2006). The regulatory environment and SMMEs' Evidence from South Africa firm level data. Development Policy Research Unit. Working Paper 06/113, pp. 1-76. September.

29. RAOSOFT. (2009). Sample size calculator. Available at: http://www.ezsurvey.com/samplesize.html [Accessed: 11 January, 2015].

30. Rath, J. (2011). Promoting ethnic entrepreneurship in European cities. Eurofound. Publications Office of the European Union, Luxembourg.

31. Rogerson, C.M. \& Sithole, P.M. (2001). Rural handicraft production in Mpumalanga, South Africa: Organisation, problems and support needs, South African Geographical Journal, 83(2), pp. 149-158. 
32. Rogerson, C.M. (2010). 'One of a kind' South African craft: the developmental challenges, Africanus, 40(2), pp. 18-39.

33. Shinnar, R.S. \& Young, C.A. (2008). Hispanic immigrant entrepreneurs in the Las-Vegas metropolitan area: motivations for entry into and outcomes of self-employment, Journal of Small Business Management, 46(2), pp. 242-262.

34. Steiner, C.B. (1994). African art in transit. Cambridge: Cambridge University Press.

35. Tengeh, R.K. (2011). A business framework for the effective start-up and operation of African immigrant-owned businesses in the Cape Town Metropolitan area, South Africa. Unpublished D. Tech. thesis, Cape Peninsula University of Technology, Cape Town.

36. Van Tubergen, F. (2005). Self-employment of immigrants: a cross-national study of 17 Western societies, Social Forces, 84(2), pp. 709-732.

37. Zikmund, W.G., Babin, B.J., Carr, J.C. \& Griffin, M. (2010). Business research methods. 8th ed. Toronto: SouthWestern Cengage/Nelson.

38. Van Tubergen, F. (2005). Self-employment of immigrants: a cross-national study of 17 Western societies, Social Forces, 84(2), pp. 709-732. 